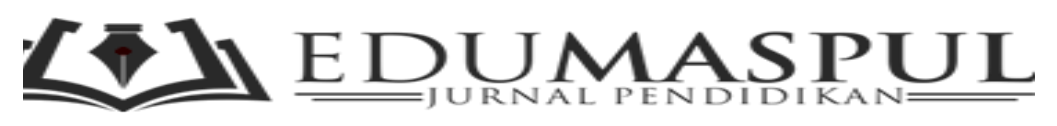

Vol. 5 - No. 1, year (2021), page 89 - 95

I ISSN 2548-8201 (Print) | 2580-0469)(Online) |

\title{
PENGARUH PEMBERIAN METODE PEMBELAJARAN SECARA KONVENSIONAL DAN SECARA PREFERENSI SENSORI KINESTETIK TERHADAP PRESTASI BELAJAR PADA MAHASISWA KEDOKTERAN UNIVERSITAS MUHAMMADIYAH JAKARTA
}

\author{
Fanny S. Farhan, Esy Risdianti \\ Fakultas Kedokteran dan Kesehatan Universitas Muhammadiyah Jakarta \\ Jl. KH Ahmad Dahlan Cirendeu Tangerang Selatan Indonesia \\ Corresponding Author: fannybudiyan@gmail.com
}

\begin{abstract}
Each individual has a different learning style. By knowing their learning styles one will more easily process and understand the lessons. This study aims to know the effect of teaching method using conventional methods compare with kinesthetic sensory preference methods in learning achievement of Universtity Muhammadiyah Jakarta medical students. 42 students with kinesthetic learning preferences were divided into two groups. The first group was given a content about blood pressure examination in conventional learning methods. The second group was given a content about blood pressure examination in the kinesthetic learning style. there was a written test to evaluate the effect of using these two methods. The results showed that there were significant differences between conventional methods and sensory kinesthetic preference methods. The conclusion is learning with suitable preferences will produce better learning achievements.
\end{abstract}

Keywords : Learning styles preferences, academic performance, medical students, kinesthetic sensory preferences.

\section{Abstrak}

Penelitian ini bertujuan untuk mengetahui pengaruh penggunaan metode pembelajaran secara konvensional dan secara preferensi sensori kinestetik terhadap prestasi belajar pada mahasiswa kedokteran Universitas Muhammadiyah Jakarta. Sebanyak 42 mahasiswa dengan preferensi sensori kinestetik dibagi menjadi dua kelompok. Kelompok pertama diberi materi Clinicsl Skill Lab (CSL) pemeriksaan tekanan darah dengan metode konvensional. Setelah itu dilakukan tes tertulis untuk mengetahui pengaruh pengajaran dengan metode konvensional dan metode sesuai preferensi sensori kinestetik terhadap prestasi belajar. Hasilnya didapatkan bahwa terdapat perbedaan yang bermakna antara metode konvensional dengan metode preferensi sensori kinestetik. Kesimpulannya adalah seseorang yang belajar sesuai preferensi sensori nya akan menghasilkan prestasi belajar yang lebih baik daripada metode konvensional.

Kata kunci : Gaya belajar, prestasi belajar, metode konvensional, preferensi kinestetik 


\section{Pendahuluan}

Belajar merupakan proses yang dilakukan oleh manusia untuk mendapatkan aneka ragam kemampuan, keterampilan, dan sikap. Menurut Syah M (2010), secara kuantitatif, belajar berarti kegiatan pengisian atau pengembangan kemampuan kognitif dengan fakta sebanyak-banyaknya. Jadi belajar dalam hal ini dipandang dari sudut berapa banyak yang dikuasai siswa. Secara institusional, belajar di pandang sebagai proses validasi (pengabsahan) terhadap penguasaan mahasiswa atas materi-materi yang telah ia pelajari. Bukti institusional yang menunjukkan mahasiswa telah belajar dapat diketahui dalam hubungannya dengan proses mengajar. Ukurannya ialah, semakin baik mutu mengajar yang dilakukan dosen makan akan semakin baik pula mutu perolehan mahasiswa yang kemudian dinyatakan dalam bentuk skor atau nilai. Adapun pengertian belajar secara kualitatif (tinjauan mutu), ialah proses memperoleh arti-arti dan pemahaman-pemahaman serta cara-cara menafsirkan dunia disekeliling mahasiswa. Belajar dalam pengertian ini di fokuskan pada tercapainya daya pikir dan tindakan yang berkualitas untuk memecahkan masalahmasalah yang kini dan nanti dihadapi mahasiswa.

Belajar dan gaya belajar adalah dua hal yang tidak terpisahkan. Setiap individu memiliki gaya belajar yang berbeda-beda. Individu yang mengenali gaya belajarnya akan lebih mudah memproses dan memahami materi. Gaya belajar merupakan kecenderungan untuk mengadaptasi suatu strategi belajar tertentu dengan mencari dan mencoba secara aktif, sehingga pada akhirnya individu mendapatkan satu pendekatan belajar yang sesuai dengan tuntutan belajar.

Ada banyak model dan alat untuk menilai gaya belajar. Menurut Othman (2010), model gaya belajar yang dikenal yaitu
Visual (V), Aural (A), dan Kinesthetic (K) atau disingkat menjadi VAK. Oleh Fleming dan Mills, menambahkan satu modalitas tambahan yaitu Read or Write (R) atau Baca / Tulis, sehingga menjadi 4 gaya belajar yakni VARK (Ojah, 2017). Mode-mode ini sering disebut sebagai "Preferensi Mode Sensori Seseorang." Seseorang dapat menunjukkan tidak memiliki gaya belajar (no preference), menggunakan satu gaya belajar (unimodal), dan gaya belajar campuran (multiple modes) yakni terdiri dari kombinasi dua gaya belajar (bimodal), maupun kombinasi tiga gaya belajar (trimodal). Dari keempat gaya belajar VARK, secara teori dikatakan bahwa gaya belajar kinestetik merupakan gaya belajar yang paling baik dalam belajar. Berdasarkan Fleming, mode visual menerima pembelajaran melalui grafik, angka grafik, dan gambar. Mode aural (A) cenderung mendapatkan informasi dengan diskusi dan mendengarkan. Mode baca/tulis (R), mengambil informasi melalui tulisan dan membaca dari yang kata-kata yang dicetak. Sementara mode kinestetik mendapatkan pemahaman yang lebih baik tentang materi melalui contoh dan aplikasi konkret.

\section{Metode Penelitian}

Penelitian ini menggunakan metode eksperimental dengan pendekatan kuantitatif. Penelitian dilakukan pada bulan Oktober sampai November 2018 di Fakultas Kedokteran dan Kesehatan Universitas Muhammadiyah Jakarta (FKK UMJ). Populasi dalam penelitian ini adalah mahasiswa semester 1 Program Studi Kedokteran Universitas Muhammadiyah Jakarta (PSPD FKK UMJ). Sampel adalah mahasiswa dengan preferensi sensori kinestetik sejumlah 42 mahasiswa. Variabel independen dalam penelitian ini adalah gaya belajar kinestetik, yang didapat dengan penggunaan Kuesioner VARK 7.8 dan variabel dependen adalah prestasi belajar yang dinilai dari kemampuan 
Jurnal Edumaspul, 5(1), Year 2021-91

Fanny S. Farhan, Esy Risdianti

mahasiswa menjawab soal materi Pemeriksaan tekanan darah. Kuesioner VARK terdiri dari enam belas butir pertanyaan, dengan empat opsi pilihan yang merupakan komponen penilaian meliputi : visual, auditori, baca/tulis, kinestetik. Jumlah skor tertinggi dari 4 komponen tersebut, menandakan gaya belajar seseorang.

\section{Hasil dan Pembahasan \\ Gaya Belajar}

Tabel 1 Distrbusi Responden Gaya Belajar

\begin{tabular}{llll}
\hline No & $\begin{array}{l}\text { Gaya } \\
\text { Belajar }\end{array}$ & Jumlah & Persentase \\
\hline 1 & Visual & 16 & 13,4 \\
2 & Auditori & 38 & 32 \\
3 & Baca/Tulis & 23 & 19,3 \\
4 & Kinestetik & 42 & 35,3 \\
\hline & Total & $\mathbf{1 1 9}$ & $\mathbf{1 0 0}$ \\
\hline
\end{tabular}

Setelah dilakukan penapisan gaya belajar dengan kuesioner VARK versi 7.8, didapatkan hasil bahwa gaya belajar tipe kinestetik dan tipe auditori adalah yang paling dominan pada mahasiswa PSPD FKK UMJ. Tipe kinestetik berjumlah 42 mahasiswa (35,3\%) dan tipe auditori berjumlah 38 orang (32\%). Pada penelitian ini yang menjadi responden adalah mahasiswa dengan preferensi belajar kinestetik. Mahasiswa ini dibagi menjadi 2 kelompok masing-masing terdiri dari 21 mahasiswa yang akan mendapatkan pembelajaran secara konvensioanl dan kelompok lainnya akan mendapatkan pembelajaran sesuai preferensi kinestetiknya.

\section{Prestasi Belajar dengan Metode Konvensional}

21 mahasiswa dengan preferensi belajar kinestetik menjalani proses pembelajaran mengenai tekanan darah dengan metode belajar konvensional. Metode konvensional berupa pembelajaran satu arah dari dosen, diruang kuliah dimana pengajar menggunakan power point dan mahasiswa Copyright (C) 2021 Edumaspul - Jurnal Pendidikan (ISSN 2548-8201 (cetak); (ISSN 2580-0469 (online) mendengarkan pengajaran seperti yang biasa dilakukan di ruang perkuliahan. Setelahnya mahasiswa diberikan tes tertulis untuk menilai hasil pembelajaran.

Tabel 2 Distribusi nilai responden setelah proses belajar metode Konvensional

\begin{tabular}{llll}
\hline No & Nilai & Jumlah & $\begin{array}{l}\text { Persent } \\
\text { ase }\end{array}$ \\
\hline 1 & $\begin{array}{l}(80-100) \\
(68- \\
79,99)\end{array}$ & 7 & $\begin{array}{l}33,3 \\
47,6\end{array}$ \\
3 & $\begin{array}{l}79,9- \\
(56- \\
67,99) \\
4\end{array}$ & 4 & 19 \\
& $\begin{array}{l}(45- \\
55,99)\end{array}$ & - & - \\
5 & $(0-44,99)$ & - & - \\
\hline & Total & $\mathbf{2 1}$ & $\mathbf{1 0 0}$ \\
\hline
\end{tabular}

Berdasarkan tabel 2 terlihat bahwa $47,6 \%$ mahasiswa mendapatkan nilai 68-79,99 dan $33,3 \%$ mendapatkan nilai diatas 80 .

\section{Prestasi Belajar dengan Metode Preferensi Sensori Kinestetik}

21 mahasiswa dengan preferensi belajar kinestetik menjalani proses pembelajaran mengenai tekanan darah dengan metode belajar sesuai preferensi belajarnya yaitu kinestetik. Metode belajar kinestetik dengan cara memperbanyak aktivitas fisik dan gerak, menggunakan ekspresi dan Bahasa tubuh, serta langsung mempraktikkan materi pembelajaran. Setelahnya mahasiswa diberikan tes tertulis untuk menilai hasil pembelajaran. Hasil tercantum dalam table 3 .

Tabel 3 Distribusi nilai responden setelah proses belajar dengan metode Preferensi Sensori Kinestetik 
Jurnal Edumaspul, 5(1), Year 2021-92

Fanny S. Farhan, Esy Risdianti

Berdasarkan tabel 3 terlihat bahwa 42,8\% mahasiswa mendapatkan nilai 68-79,99 dan $38,1 \%$ mendapatkan nilai diatas 80 .

\section{Perbandingan Prestasi Belajar antara Metode Konvensional dan Metode Preferensi Sensori Kinestetik}

Setelah dilakukan uji t-test didapatkan nilai $\mathrm{p}$ 0.038 yang artinya terdapat perbedaan signifikan antara kelompok mahasiswa yang mendapatkan pembelajaran dengan metode konvensional dibandingkan dengan mahasiswa yang mendapatkan pembelajaran secara kinestetik.

Berdasarkan hasil penelitian diatas diketahui bahwa mahasiswa PSPD FKK UMJ 2018 secara dominan memiliki kecenderungan gaya belajar kinestetik (35,3\%).

Hasil penelitian ini berbeda dengan hasil penelitian yang dilakukan oleh Turky $\mathrm{H}$. Almigbal (2015) dari King Saud University di Riyadh, dengan responden mahasiswa kedokteran, dan total sampel sebanyak 600 mahasiswa. Yang menggunakan seluruh komponen gaya belajar dari VARK sebanyak 261 dengan persentase 43,5\%, aural sebanyak 127 orang dengan persentase $21,2 \%$, visual sebanyak 97 orang dengan persentase $16,2 \%$, kinestetik sebanyak 64 orang dengan persentase $10,7 \%$, baca/tulis sebanyak 34 orang dengan persentase $5,7 \%$, dan bimodal sebanyak 17 orang dengan persentase $2,7 \%$.

Jindal, dkk (2013) juga melakukan penelitian yang membandingkan gaya belajar pada mahasiswa kedokteran semester satu dan tujuh di Sharda University, Greater Noida. Didapatkan hasil pada mahasiswa semester satu $75 \%$ memiliki unimodal gaya belajar paling banyak yaitu Auditori (44\%), diikuti Kinestetik (17\%). Sedangkan pada

\begin{tabular}{llll}
\hline No & $\begin{array}{l}\text { Prestasi } \\
\text { Belajar }\end{array}$ & Jumlah & $\begin{array}{l}\text { Persentas } \\
\text { e }\end{array}$ \\
\hline 1 & $(80-100)$ & 8 & 38,1 \\
2 & $(68-79,99)$ & 9 & 42,8 \\
3 & $(56-67,99)$ & 4 & 19 \\
4 & $(45-55,99)$ & - & - \\
5 & $(0-44,99)$ & - & - \\
\hline & Total & $\mathbf{2 1}$ & $\mathbf{1 0 0}$ \\
\hline
\end{tabular}

mahasiswa semester tujuh unimodal (45\%), multimodal(55\%). Pada unimodal yang paling banyak digunakan kinestetik (24\%), diikuti auditori (13\%). Pada penelitian Jindal, dkk (2013) diperoleh bahwa semester satu kecenderungan gaya belajar adalah auditori, dan semester tujuh adalah kinestetik. Dalam penelitiannya juga ditemukan bahwa mahasiswi cenderung menggunakan gaya belajar auditori, sedangkan mahasiswa cenderung menggunakan gaya belajar kinestetik.

Hasil yang berbeda-beda dari kuesioner VARK menunjukkan bahwa setiap mahasiswa memiliki gaya belajar yang bervariasi. Ini merupakan hal yang lazim karena setiap orang memiliki karakteristiknya masingmasing. Penelitian jindal, dkk menunjukkan bahwa adanya faktor-faktor yang mempengaruhi proses belajar. Secara umum terbagi menjadi tiga macam, yaitu faktor internal (faktor fisiologis dan faktor psikologis) yakni keadaan atau kondisi jasmani dan rohani individu, faktor eksternal (faktor sosial dan nonsosial) yakni kondisi lingkungan di sekitar individu, faktor pendekatan belajar, yakni jenis upaya belajar individu yang meliputi strategi dan metode yang digunakan untuk melakukan kegiatan pembelajaran materi-materi pembelajaran.

\section{Prestasi Belajar pada Metode Konvensional}

Berdasarkan penelitian didapatkan bahwa prestasi belajar dengan metode konvensional pada mahasiswa PSPD FKK UMJ menunjukkan bahwa yang mendapatkan rentang nilai 6879,99 berjumlah 10 orang dengan persentase $47,6 \%$ merupakan nilai yang paling dominan didapatkan mahasiswa pada hasil tes tertulis 
Jurnal Edumaspul, 5(1), Year 2021-93

Fanny S. Farhan, Esy Risdianti

ini. Paling sedikit ada pada rentang nilai 56,67-67,99 berjumlah 4 orang sama dengan kelompok kinestetik dengan persentase $19 \%$. Penelitian yang dilakukan oleh oleh Datta $\mathrm{R}$, dkk (2015) yang membandingkan dua metode yakni kelas dengan metode konvensional dan kelas interaktif pada mahasiswa kedokteran di india. Datta $R$, dkk melakukan penilaian melalui pre-test dan post-test. Didapatkan perbedaan yang bermakna, yaitu kelas interaktif menghasilkan post-test yang lebih baik dibandingkan kelas metode konvensional dengan nilai $p=0,001$. Hasil ini konsisten dengan pernyataan oleh Wiggins (1987) yang melaporkan bahwa interaksi antara dosen dan mahasiswa selama proses belajarmengajar mendorong siswa untuk mencari pengetahuan daripada dosen memonopoli transmisi informasi ke peserta didik.

Hasil ini membuktikan pada metode konvensional, interaksi dan perhatian dosen kepada mahasiswa kurang. Sehingga keterlibatan mahasiswa dalam proses belajar sangatlah minim akibatnya hasil belajar yang diinginkan tidak tercapai. Serta memberikan kesulitan pada mahasiswa dalam menentukan dan menggunakan preferensi sensori yang seharusnya memudahkan mahasiswa dalam kegiatan belajar, terutama pada mahasiswa yang sebelumnya tidak tahu gaya belajarnya sendiri. Sehingga mahasiswa tidak maksimal menggunakan preferensi sensori yang dominan baginya, akibatnya tidak efektif dan optimal dalam menyerap informasi.

\section{Prestasi Belajar pada Metode Preferensi Sensori Kinestetik}

Berdasarkan penelitian didapatkan bahwa prestasi belajar dengan metode gaya belajar kinestetik pada pada mahasiswa PSPD FKK UMJ yang mendapatkan mendapatkan rentang nilai 68-79,99 berjumlah 9 orang dengan persentase $42,8 \%$ merupakan nilai yang paling dominan didapatkan mahasiswa pada hasil tes tertulis ini, paling sedikit ada pada rentang nilai 56,67-67,99 berjumlah 4 orang dengan persentase $19 \%$.

Hal ini sejalan dengan penelitian yang dilakukan Wardani RA (2015) yang membandingkan pengaruh metode ceramah dan metode demonstrasi terhadap prestasi belajar mata kuliah asuhan persalinan normal. Metode demonstrasi menerapkan metode yang hampir mirip dengan preferensi sensori kinestetik. Hasilnya didapatkan bahwa metode demonstrasi lebih baik dibandingkan metode ceramah (konvensional). Dengan rata-rata nilai 80,9 sedangkan metode ceramah rata-rata nilai 76,5 .

Secara teori yang dijelaskan bahwa gaya belajar merupakan memori sensorik. Memori sensorik adalah segala sesuatu aspek yang melalui indera manusia yang menyebabkan terjadinya penyimpanan tanpa sengaja (tanpa disadari) dalam bentuk jejak memori sensorik berupa pengetahuan episodik. Pengetahuan episodik ini sifatnya involunter sehingga relatif lebih cepat mengalami proses degredasi. Oleh sebab itu, pentingnya atensi terhadap memori sensorik pada setiap pengalaman. Agar dimasukkan kedalam memori kerja, sekali sebuah pengalaman dimasukkan ke memori kerja maka orang tersebut dapat dengan sadar mengingat setiap memori dan memikirkannya dalam bentuk konteks.

Pada penelitian ini, mahasiswa diberikan pengajaran sesuai dengan gaya belajar kinestetik yaitu belajar melalui aktivitas fisik, mahasiswa yang mempunyai gaya belajar kinestetik belajar melalui pengalaman fisik dan praktik termasuk didalamnya yaitu bergerak, menyentuh, dan melakukan. Mereka tidak tahan untuk duduk berlamalama mendengarkan pelajaran dan merasa bisa belajar lebih baik jika prosesnya disertai kegiatan fisik. Gaya belajar merupakan cara mahasiswa berkonsentrasi, dan metode mereka dalam memproses dan memperoleh informasi, pengetahuan, atau pengalaman. 
Jurnal Edumaspul, 5(1), Year 2021-94

Fanny S. Farhan, Esy Risdianti

Maka penting bagi mahasiswa untuk mengetahui gaya belajarnya.

Adanya penyesuaian dalam memberikan pengajaran sesuai gaya belajar kinestetik memberikan hasil prestasi belajar yang lebih baik dari pada metode konvensional.

\section{Perbandingan Prestasi Belajar antara Metode Konvensional dan Metode Preferensi Sensori Kinestetik}

Setelah dilakukan pengujian SPSS dengan independent sample $t$ test didapatkan hasil $p$ value 0,038 yang artinya terdapat perbedaan prestasi belajar pada mahasiswa PSPD FKK UMJ yang diberi metode pembelajaran secara konvensional dan secara preferensi sensori kinestetik. Nilai rata-rata pada metode konvensional adalah 68 dan metode preferensi sensori kinestetik adalah 73,3.

Hasil penelitian ini sesuai dengan penelitian yang dilakukan oleh Ganyaupfu EM (2013) tentang pengaruh metode pengajaran dan prestasi akademik mahasiswa. Metode pengajaran yang dinilai ada tiga yaitu : Teacher-Centered Methods, StudentCentered Methods, dan Teacher-Student Interactive Methods. Hasilnya didapatkan bahwa Teacher-Student Interactive (mean = $1,89)$ adalah yang paling efektif. Sedangkan metode yang paling rendah adalah TeacherCentered Methods (mean $=1,39$ )

Sebagaimana Metode konvensional yang menerapkan pembelajaran berpusat pada guru atau dosen (Teacher Centered Learnning). Menurut Hake (1998) Teacher Centered Learning mengakibatkan mahasiswa sedikit atau tidak terlibat sama sekali dalam proses belajar, sehingga menghasilkan prestasi akademik yang kurang memuaskan pula.Serta metode ceramah (konvensional) menuntut mahasiswa untuk menggunakan seluruh preferensi sensori. Sedangkan setiap individu memiliki dominan preferensi sensori nya masing-masing. Maka proses belajar nya tidak optimal dan efektif. Sedangkan pada metode preferensi sensori kinestetik menerapkan gaya belajar mahasiswa. Bobbi Deporter dan Hernacki menyatakan apabila seseorang akrab dengan gaya belajar sendiri maka ia dapat mengambil langkah-langkah penting untuk membantunya dalam belajar lebih cepat dan lebih mudah.Oleh karena itu penting bagi setiap individu untuk mengetahui gaya belajarnya, agar tercapai hasil pembelajaran yang diinginkan. Dari hasil penelitian ini kesimpulannya adalah metode preferensi sensori kinestetik menghasilkan prestasi belajar yang lebih baik dibandingkan metode konvensional.

\section{Kesimpulan}

Dari hasil data distribusi 119 mahasiswa didapatkan gaya belajar mahasiswa Program Studi Kedokteran Universitas Muhammadiyah Jakarta paling banyak memiliki kecenderungan gaya belajar tipe kinestetik berjumlah 42 (35,3\%) diikuti gaya belajar auditori berjumlah 38 (32\%). Setelah dibandingkan dari dua kelompok yang menjalani proses pembelajaran konvensional dibandingkan dengan kinestetik, dapat diambil kesimpulan bahwa seseorang yang belajar sesuai preferensi sensorinya menghasilkan prestasi belajar yang lebih baik.

\section{Daftar Pustaka}

Data R et al. (2015). evaluation of interactive teaching for undergraduate medical students using a classroom interactive response system in India. 71(3):239-245.

Ganyaupfu EM. (2013). Teaching methods and students academic performance.2(9):2935.

Jindal $M$ et al. (2013). Comparative analysis of instructional learning preferences of medical students of first and seventh semester. 1(1):32-35.

Kharb P, Samanta PP, Singh V. (2013). The Learning Styles and the Preferred TeachingLearning Strategies of First Year Medical Students. J Clin Diagn Res. 7(6): 1089-1092 
Ojeh N, Sobers-Grannum N, Gaur U, Udupa A, Majumder MAA. (2017). Learning style preferences: A study of preclinical medical students in Barbados. J Adv Med Educ Prof. 5(4):185-194.

Othman N et al. (2010). Different perspectives of learning styles from VARK model. Malaysia: Elsevier.

Prithishkumar I J, Michael S A. (2014). Understanding your student: Using the VARK model. J Postgrad Med.60:183-6

Syah M. (2010). Psikologi belajar. Ed. Rev-10. Jakarta: rajawali Pers

Turky HA. (2015). Relationship between the learning style preference and academic achievement. 36(3);330

Wardani RA (2015). Pengaruh metode demonstrasi terhadap prestasi belajar mata kuliah ASKEB II persalinan ditinjau dari motivasi belajar pada mahasiswa prodi kebidanan stikes Dian Husada Mojokerto. 6667 